\title{
海水減少を考慮したオホーツク海における波浪の将来変化
}

\section{Future Changes in Sea of Okhotsk Wave Characteristics in Consideration of Reduced Sea Ice Cover}

\author{
菅原吉浩 $^{1} \cdot$ 山之内 川 $^{2} \cdot$ 山本泰司 $^{3}$ \\ Yoshihiro SUGAWARA, Jun YAMANOUCHI and Yasuji YAMAMOTO
}

\begin{abstract}
The authors proposed a precise wave hindcasting method for areas of sea ice that allows wind speed reduction in line with the level of sea ice concentration. Consequently, the reproducibility of significant wave heights and wave periods was improved in comparison to results obtained with the conventional approach, in which areas of sea ice were considered as land. Using the proposed method, future changes in the 50-year stochastic wave height for the Sea of Okhotsk were also determined in consideration of reduced sea ice cover.
\end{abstract}

\section{1. はじめに}

気候変動による北海道周辺の波浪の将来変化を検討す る上で，オホーツク海に面する北海道では海水の影響を 考慮した波浪推算を行う必要がある。しかし, 水海域で の波浪推算手法については，通常は海水で覆われている 部分を陸地とみなすことが多く（例えば，水口ら，2009. 以下, 従来手法), この場合, 水海域での波浪の発達お よび減衰が全く考慮されないことが問題となる．本研究 では，従来手法よりも再現性が高い波浪推算手法につい て波浪推算モデルSWANを用いて検討する．また流水の 減少による将来気候での 50 年確率波高（以下， $H_{50}$ ）の 変化について, 気象庁・気象研究所による超高解像度全 球気候モデル（以下，MRI-AGCM3.2S）の温暖化予測実 験結果（Mizuta ら，2012）と，本研究で構築した波浪推 算手法により検討する.

\section{2. 氷海域における波浪推算}

\section{(1) 検討方法}

計算領域は図-1のように2段階ネスティングで実施し た. 格子間隔は第 1 領域で $0.1^{\circ}$, 第 2 領域で $1 / 30^{\circ}$ とし, 時間ステップは第 1 領域で $10 \mathrm{~min}$, 第 2 領域で $5 \mathrm{~min}$ とした. 周波数分割数は 30 成分 $(0.04 \sim 1.0 \mathrm{~Hz})$, 方向スペクトル 分割数は36成分とした。風による波の発達項については Janssen（1991）を用いた。海上風データは気象庁の GSM $\left(0.5^{\circ} \times 0.5^{\circ}\right)$ 及びMSM $\left(0.0625^{\circ} \times 0.050^{\circ}\right)$ による再解析 データを用いた。再現計算期間は，近年 5 力年で海水面 積が多い2010年および面積が少ない2009年のそれぞれ について, 海水来襲時期の 1 月〜 3月を対象とした.

推算值と比較する観測波浪データは, NOWPHAS 紋別

\begin{tabular}{|c|c|c|}
\hline 1 & & 水産庁 漁港漁場整備部 整備課 \\
\hline $\begin{array}{l}2 \\
3 \text { 正会員 }\end{array}$ & 博(工) & $\begin{array}{l}\text { (独法) 土木研究所 寒地土木研究所 } \\
\text { (独法) 土木研究所 寒地土木研究所 }\end{array}$ \\
\hline
\end{tabular}

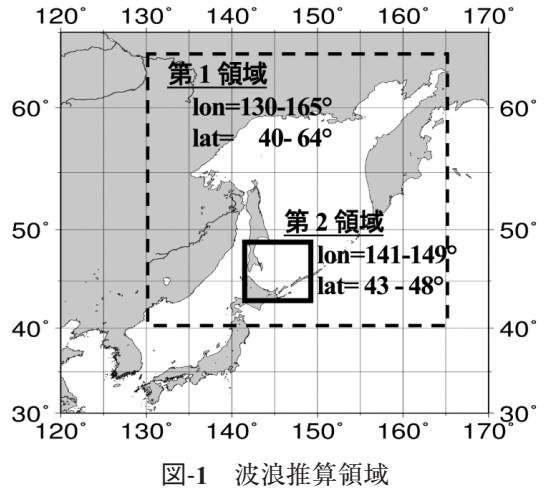

表-1 水海域の波浪推算手法の一覧

\begin{tabular}{c|c|c|c}
\hline 手法 & $\begin{array}{c}\text { 陸域とする海水 } \\
\text { 密接度の境界 }\end{array}$ & $\begin{array}{c}\text { 推算期間中の } \\
\text { 海水分布 }\end{array}$ & $\begin{array}{c}\text { 風速の } \\
\text { 調整 }\end{array}$ \\
\hline $1-1$ & 4以上を陸域 & 5 日毎に移動 & 無し \\
\hline $1-2$ & 7以上を陸域 & 5 日毎に移動 & 無し \\
\hline 2 & - & 5 日毎に移動 & 有り \\
\hline 3 & - & 無し & 無し \\
\hline
\end{tabular}

（水深 50m, $\mathrm{N} 44.318^{\circ}, \mathrm{E} 143.607^{\circ}$ ）を用いた. 海水分布は, 気象庁がweb上で公開している5日毎の海水密接度（海 水密集割合を 10 分位法で表したもの）の画像データから RGBカラー情報を数值化した.

本研究で比較検討する波浪推算手法を表-1に示す。手 法1-1および1-2 は，氷海域を陸域とみなす従来手法であ るが，SWANのHOTFILEコマンドにより，計算終了時 点の境界条件を次の計算ステップの初期条件とすること により，陸域とみなした海水の移動も考慮している。な お，気象庁の海水分布図の更新間隔と同様に，本検討で は 5 日毎に海水を移動させる.手法 2 は, 海水密接度に 応じて風速を低減させる方法である。この手法の詳細は 2.（3）で述べる，手法 3 は，海水を全く考慮せずに，再 解析データの風速をそのまま用いる方法とした. 


\section{（2）水海域における波高の伝播}

水海域での波浪減衰に関する既往の研究事例としては, Wadhams（1975）がニューファンドランド沖での観測結 果を踏まえ，水板下の波高伝達率 $K_{t}$ が周期および水板厚 の影響を受けることを確認している，また，堺ら（1996） は水理模型実験により, 水板下の波高が伝播距離 $x$ に応 じて指数関数的に減少すること, および氷板厚さ別の $K_{t}$ を示している，なお， $K_{t}$ は，下記の式で表される.

$$
\begin{aligned}
& K_{t}=\exp (-A x) \\
& A=B \cdot f^{n}
\end{aligned}
$$

ここに, $K_{t}$ : 水板下の波高の伝達率, $A$ : 隇衰パラメー夕 一, $x$ : 水板下の伝播距離 $(\mathrm{m}), B, n$ : 水厚別のパラメ 一ター, $f:$ 波の周波数 $(\mathrm{Hz})$

一方, 氷海域での波の発達は, 海水部分では波を発達 させずに式（1）による減衰のみを考慮し，海氷以外の海 水面では発達項により波を発達させれば良い。これら減 衰掞よび発達の両波高を合成した波高（以下，目標波高） が，水海域において伝播していくものと考えられる.

\section{（3）手法 2 の 1 次元数值水路での再現性}

SWANに打ける波の発達項はPhillipsの共鳴機構による 線形増大項と Milesの不安定機構に基づく指数関数項の 2 種類あるが，本検討ではJ Janssenの指数関数項のみを考虑 している，すなわち，風速を小さくすることで，指数関 数的に減衰する目標波高を再現できるはずである．この ことについて，図-2のSWAN1 次元水路により検討を行 った，水路長 $500 \mathrm{~km} ，$ 水深は底面摩擦等の影響を受けな いよう $500 \mathrm{~m}$ とし, 風速を $10 \mathrm{~m} / \mathrm{s}$ から $40 \mathrm{~m} / \mathrm{s}$ の 4 ケース, 境界での有義波高を $2 \mathrm{~m}, 5 \mathrm{~m}, 8 \mathrm{~m}$ の 3 ケース，周期を $8 \mathrm{~s}$, $10 \mathrm{~s} ， 12 \mathrm{~s}$ の 3 ケースとし，風速を 0 から $100 \%$ の間で $5 \%$ 刻 みで変化させ，目標波高に最も近づく風速低減率を検討 した、減衰パラメーターAは，堺らの実駼縮尺を $1 / 100$ とした場合に，現地スケールで $1.0 \mathrm{~m}$ の水厚に相当するも のを用いた。 また，実海域では海氷密接度が同じでも海 氷の分布範囲が異なることから, 乱数により密接度毎に SWANの 1 次元水路内の海水分布を 5000 種類に変化さ せ，各分布毎に算出した目標波高を平均した。

図-3に手法 2 による再現結果の一例を示す．流水が無 い状態では $30 \mathrm{~m} / \mathrm{s}$ の風速により破線のように波が発達す るが，各密接度に応じて風速を減少させることで，水海 域に扔ける波の伝播（目標波高）が概ね再現されている.

図-4に，最確值を目標波高とした場合の誤差の二乗平 均平方根 $(R M S E)$ とRMSEが最小となる最適風速低減率 の関係を示す．密接度が増大するにつれて RMSEも大き くなるが，これは，図-3の密接度8の場合にみられるよ うに，密接度が大きい場合には $x=0 \sim 50 \mathrm{~km}$ の範囲におい て，風速の低減だけでは十分に波高が減衰しないことに
Wind Speed $10 \sim 40 \mathrm{~m} / \mathrm{s}$

Boundary (rate of reduction $0 \sim 100 \%$ )

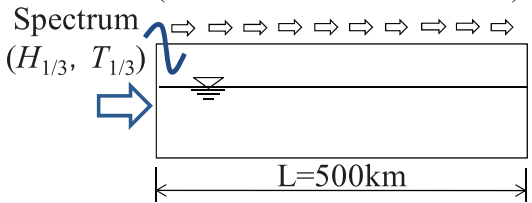

図-2 SWAN 1 次元水路イメージ
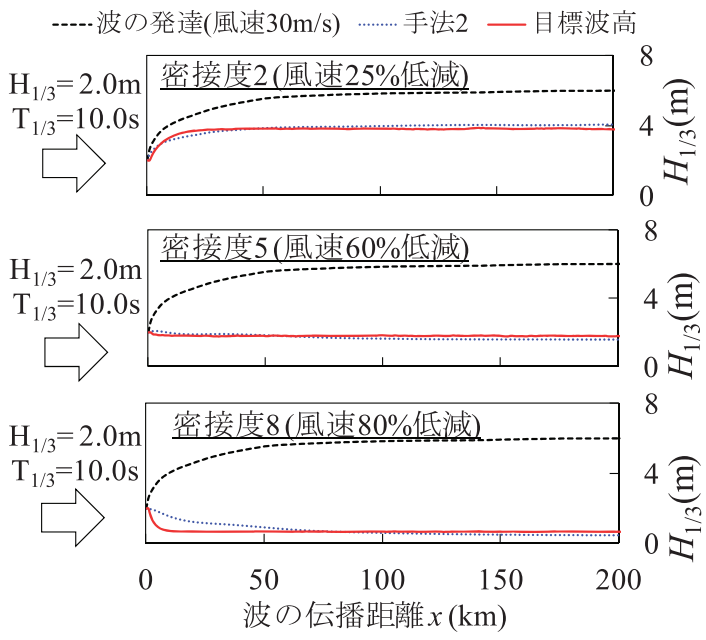

図-3 手法 2 によ水海域波高の再現例

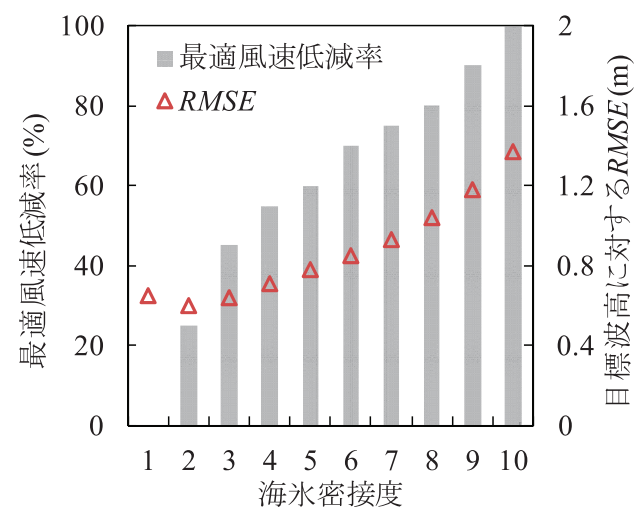

図-4＼cjkstart海水密接度每の風速低減率とRMSEの関係

よる、ただし，伝播距離が長くなるにつれて目標波高に 近づいている. 冬期の北海道のオホーック海沿岸部は, 通常 $200 \mathrm{~km}$ 以上の広い範囲で海水が接岸しているため, 実務上のRMSEは図-4に示した誤差よりも小さくなると 考えられる.

\section{（4）実水海域での有義波高の再現性}

図-5に，観測と手法 1 から手法 3 の有義波高 $H_{1 / 3}$ の経時 変化と, 図-6に観測と推算の $H_{1 / 3}$ の相関を示す。なお, 図-5の上段の海水面積は, 北海道東部沿岸から $200 \mathrm{~km}$ の 範囲内における面積を示している。従来手法の手法 1-1 

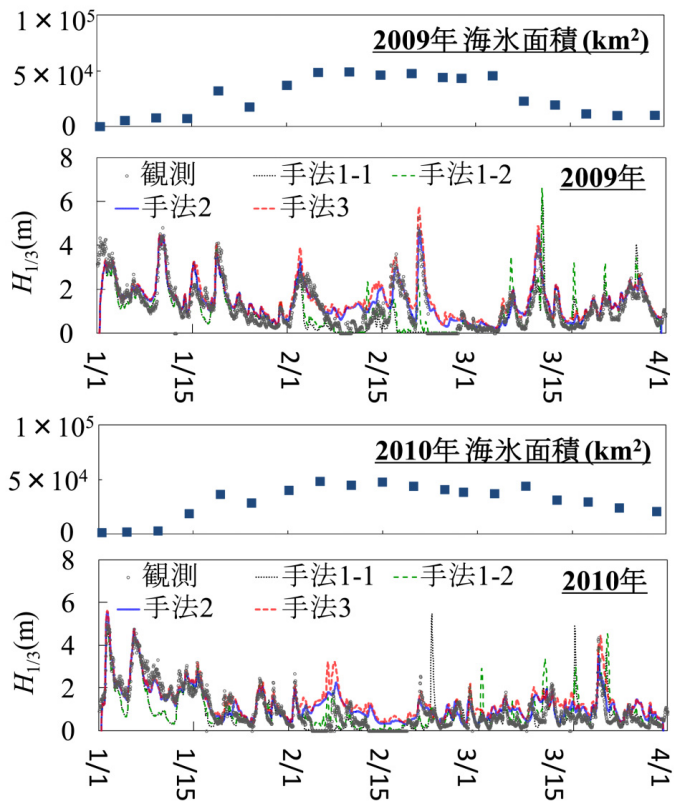

図-5 各手法の有義波高の経時変化

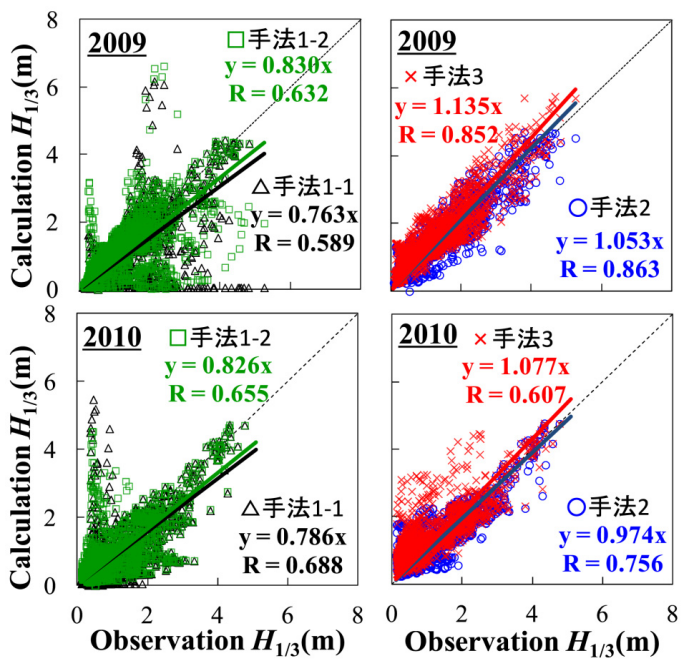

図-6 各手法と観測有義波高との相関

および手法1-2では，水海域での波の伝播を全く考慮し ないことにより，観測值に比べて $20 \%$ 程度 $H_{1 / 3}$ は小さく なっている。ただし，2010年の2月22日および3月 20 日 前後で，従来手法が観測值に比べ相当増大する場合があ る.この原因としては，高波浪領域の周囲が海水で突然 囲まれることにより，この海域では外部の海域に比べて エネルギーが減衰しづらくなり，次の計算ステップで海 水が移動するとこの海域の高波浪が周囲に伝播するため である。このように，従来手法では，氷海域を陸域とみ なすことにより，海水部分での波の減衰が過大に評価さ れ，全体的には観測值より過小となるが，海水の分布形

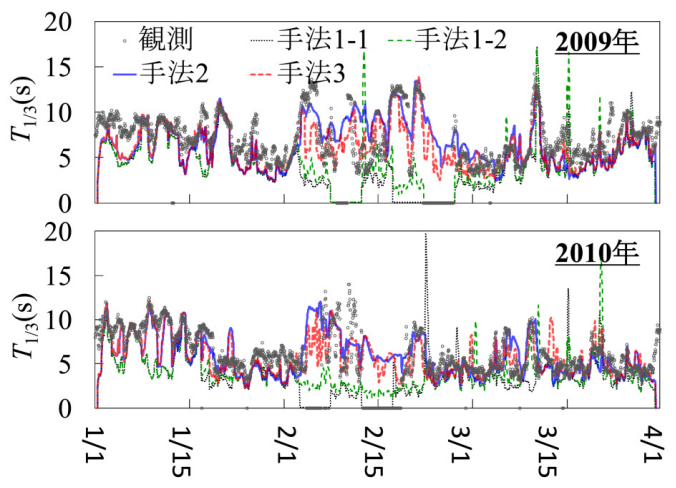

図-7 各手法の有義波周期の経時変化

状によっては観測值より過大に推算される場合もあり， 再現性に問題がある.

次に，手法 2 と手法 3 の相関を比べると，手法3では観 測波高より $10 \%$ 程度過大傾向となっているが，手法 2 で は観測值と同程度となり相関性も向上する。また，海水 が少ない2009年よりも，海水が多い2010年において相 関性の向上が大きい。例えば，2009年2月 5 日，2010年2 月 10 日や 3 月 20 日前後では，手法3では観測值を大きく 上回るが，手法2では推算波高が抑制されている。

このように，手法 2 は風速を低減させるという簡易な 手法ではあるが，実海域においても十分な再現性を有す ることが確認された。

\section{（5）実水海域での周期の再現性}

図-7に, 手法 1 から手法 3 の有義波周期 $T_{1 / 3}$ の経時変化 を示す。手法1-1 および手法1-2では，観測值に比べ相当 に小さくなるが，手法 2 や手法 3 では，経時変化が概ね 再現されている。例えば，2009年 2 月 5 日付近の $T_{1 / 3}$ をみ ると, 手法 2 は手法 3 に比べて 5 秒以上周期が長くなり再 現性が向上している.

図-8（a）は，笹島ら（1996）が提案した水海域でのス ペクトル形状と，SWANによる手法 1 ～3の計算スペク トル形状を比較したものである。横軸は周波数をピーク 周波数 $f_{\mathrm{m}}$ により 無次元化し, 縦軸は $f_{\mathrm{m}}$ と全エネルギー $E$ により無次元化している。また、図-8（b) には，この時 の海水密接度分布を, 図-8 (c) には $H_{1 / 3}$ および $T_{1 / 3}$ の経時 変化を示す。なお，1994年2月時点の気象庁MSMによる 高解像度の風速データが無いため, ここでは ECMWF $\left(0.75^{\circ} \times 0.75^{\circ}\right)$ の再解析デー夕を用いている。 スペクト ル形状をみると，観測值では高周波成分側のエネルギー が減衰し，ピーク周波数付近が鋭く尖る水海域での特徽 的なスペクトル形状となっている。しかし，手法1-1で は，観測值とは異なり高周波成分側にも多くのエネルギ 一が存在し， $T_{1 / 3}$ も観測值に比べ小さくなっている。一 方，手法2では波高ピーク時において笹島ら（1996）が 

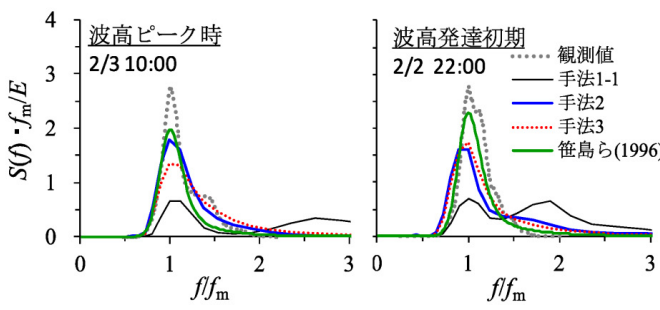

(a) スペクトル形状

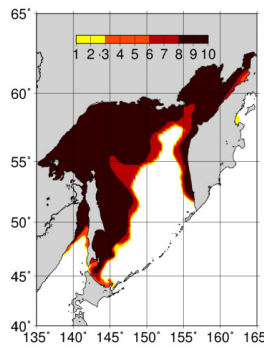

1994 年 1 月 31 日

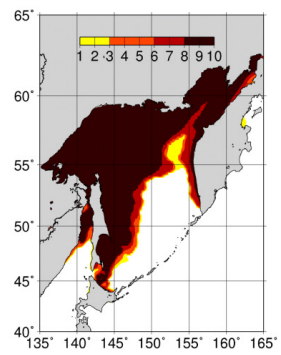

1994 年 2 月 5 日 (b) 海水密接度分布
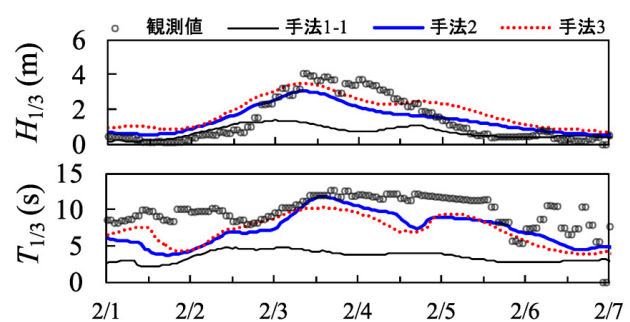

(c) $H_{1 / 3}$ および $T_{1 / 3}$ の経時変化

図-8 水海域でのスペクトル形状（1994年2月）

提案した氷海域でのスペクトル形状と同様に $f_{\mathrm{m}}$ 付近にエ ネルギーが集中し，手法3に比べて $T_{1 / 3}$ が観測值に近づい ている，このように，手法2により流水部分の風速を密 接度に応じて低減させることによって, 水海域における 特徵的なスペクトル形状を比較的良く表現できることが わかる.

\section{3. 海水減少がオホーツク海の将来波高に与える 影響}

\section{（1）検討方法}

次に, MRI-AGCM3.2S の A1B シナリオ下における地上 $10 \mathrm{~m}$ 風速 $U_{10}$ (空間解像度は約 $20 \mathrm{~km}$, 時間解像度 $3 \mathrm{hr}$ ) を 用いて, 将来気候に打ける $H_{50}$ を算出する。 ただし, 海 氷が多い 12 月から 3 月については, MRI-AGCM $3.2 \mathrm{~S}$ の境 界条件として用いられている月別の海水密接度 (水田ら, 2008）に応じて，手法2により風速を低減させた。波浪 推算の計算領域としては図-1の第 1 領域のみを対象とし た。対象期間は，1979〜2003年（現在気候），2015～

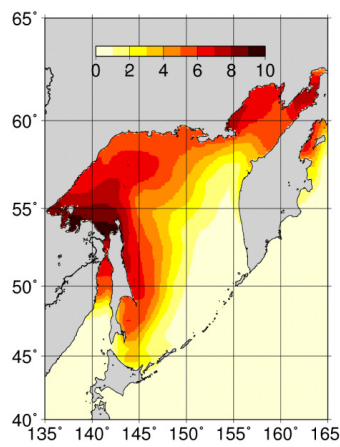

(a) 平均海水密接度

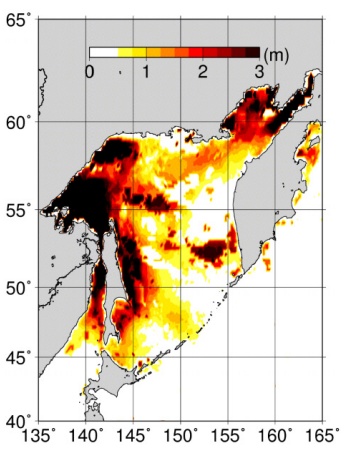

(b) $H_{50}$ の変化
図-9 海水の有無が現在気候の $H_{50}$ に与える影響

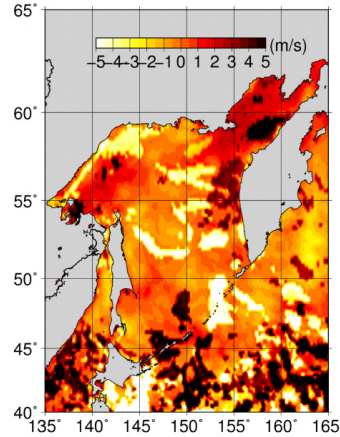

(a) 現在〜近未来

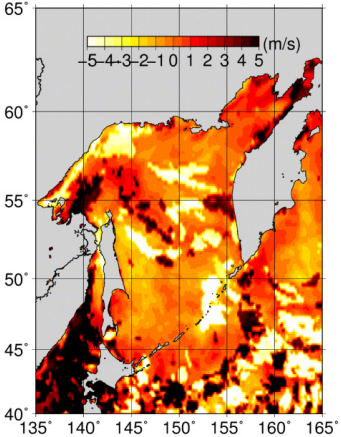

(b) 現在 将来
図-10 現在気候に対する 50 年確率風速 $W_{50}$ の将来変化

2039年（近未来気候）および2075～2099年（将来気候） の各期間 25 年分，延べ 75 年分の波浪推算を実施した. その他の波浪推算方法は, 前述 2.1 と同様としている. なお，統計処理は合田（2008）の方法とし, 閾值以上の 極大值の割合が3〜 $5 \%$ となるように格子毎に閾値を変え ている.

\section{（2）海氷の有無が 50 年確率波高に与える影響}

図-9（a）に，水田ら（2008）の月別海水分布をもとに 算出した現在気候における 12 月から 3 月の平均海水密接 度を示す。また，図-9（b）は，現在気候での海水の有無 が $H_{50}$ に与える影響として, 手法3（海水無し）と手法 2 （海水有り）による $H_{50}$ の差を示す，図より，サハリン周 辺抢よびカムチャツカ半島周辺の密接度が高い海域での 波高差が特に大きく, 北海道東部沿岸および根室半島南 部でも 1〜2mの波高差がみられる，すなわち，海水を考 慮せずに波浪推算を行うと $H_{50}$ を過大評価することにな る.また, 現在気候に対して将来気候の $H_{50}$ を相対的に 評価する場合にも，海水を考慮することが重要である.

（3）海水減少による50年確率波高の将来変化

図-10 (a) (b) に，MRI-AGCM3.2Sの $U_{10}$ をもとに算出 した，近未来気候および将来気候における現在気候に対 
する 50 年確率風速 (以下, $W_{50}$ ) の変化を示す. 近未来 気候では千島列島南東部において, 将来気候では日本海 側において $W_{50}$ が増大するなど，対象期間により $W_{50}$ の増 大領域が変化している。また，北海道周辺では，近未来 気候に比べ将来気候の方が風速の増加が顕著である.

図-11に，近未来気候㧍よび将来気候における $H_{50}$ の現 在気候に対する变化を示す，近未来気候では千島列島周 辺や日本海北西部, 将来気候では日本海側から太平洋沿 岸にかけて $H_{50}$ が大幅に増加しており，これは図-10の $W_{50}$ の変化に概ね対応しているようである。また，近未 来気候における北海道沿岸での $H_{50}$ の増加量は平均する と $0.5 \mathrm{~m}$ 未満に留まるが, 将来気候では日本海側から太平 洋にかけて 4 $5 \mathrm{~m}$, 水海域であるオホーツク海側では $H_{50}$ は $1 \mathrm{~m}$ 以上増加する。

図-12（a）に，現在気候に対する将来気候での12月か ら 3 月の平均海水密接度の変化を, 図-12 (b) には, 将来 の海水減少が $H_{50}$ に与える影響として, 風速は将来気候 で海水分布が現在気候の場合と将来気候の場合の $H_{50}$ の 差を示す。なお，海水分布が現在気候の場合では，例え ば2075年 1 月では 1979年 1 月, 2099年3月では 2003 年 3 月の海水分布というょうに，現在気候 25 年間と同じ海水 分布书よび出現順序としている.

将来気候の海水密接度は図-12 (a) より全体的に減少し ていることがわかる。また，図-12(b) より $H_{50}$ の変化が 大きい海域としては図-9 (b) と同様に，現在気候での海 氷密接度が高い地域に扔いて波高差が特に大きく, 北海 道東部でも $1 \mathrm{~m}$ 程度の波高差がみられる。このことから， 将来気候における $H_{50}$ の変化は全体的には $W_{50}$ の影響が大 きいが, 海氷密接度の大きいサハリン周辺から北海道に かけては, 海水減少の影響を受けることが確認された.

\section{4. まとめ}

本研究では, 流氷の減少がオホーツク海における波浪 の将来変化に与える影響を検討するため, 従来手法より も再現性の高い水海域での波浪推算手法を検討するとと もに, 構築した手法と気象庁・気象研究所による MRI$\mathrm{AGCM} 3.2 \mathrm{~S}$ の温暖化予測実験結果をもとに，将来の 50 年 確率波高 $H_{50}$ の変化を検討した。その結果, 従来実施さ れていた氷海域を陸域として扱う手法に比へ，海水密接 度に応じて風速を減少させることにより，有義波高およ び有義波周期, 並びに氷海域に打ける特徵的なスペクト ル形状の再現性が向上することが明らかとなった．また， 海水を考慮せずに波浪推算を行った場合には， $H_{50}$ を過 大評価することとなり，その範囲はサハリン周辺だけで なく北海道東部沿岸にまで及ぶことが確認された。さら に, 将来気候での $H_{50}$ の変化は風速増大だけでなく, 冬 期の海水減少の影響を受けることが明らかとなった。

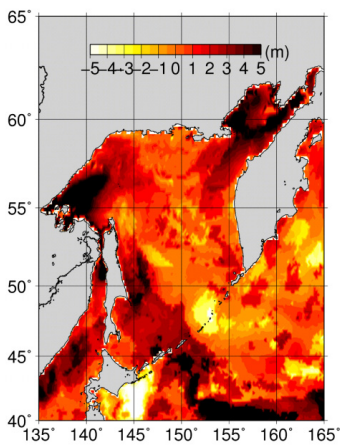

(a) 現在〜近未来

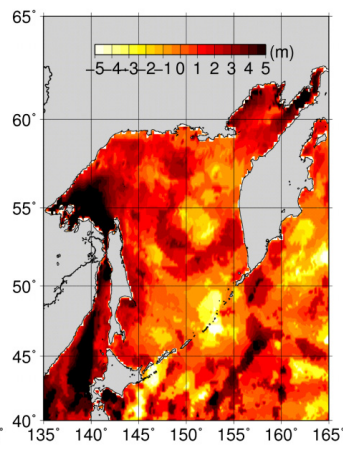

(b) 現在 将来
図-11 現在気候に対する 50 年確率波高 $H_{50}$ の将来変化

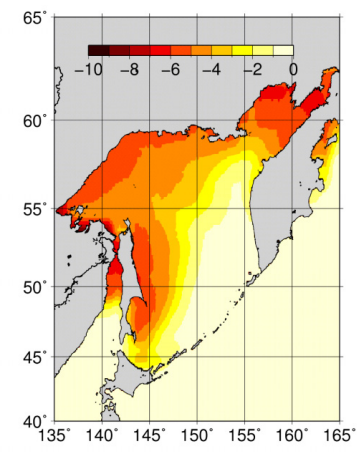

(a) 海水密接度の変化

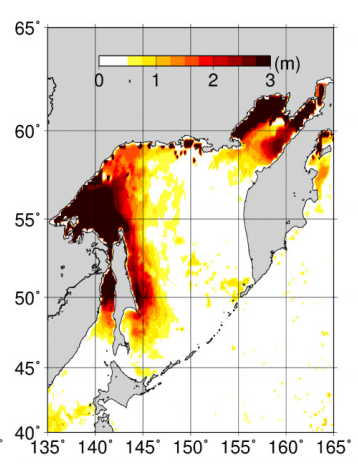

(b) $H_{50}$ の変化
図-12 将来気候における海水減少が $H_{50}$ に与える影響

謝辞 : 気象研究所から MRI-AGCM3.2S のデータを御提供 頂いた。ここに記して謝意を表す。

\section{参 考 文 献}

堺 茂樹・笹本 誠・片山潤之介・劉 暁東 - 平山健一・泉 山 耕・金田成雄（1996）：水板による不規則波の変形に 関する実験，海岸工学論文集，第43卷，pp.426-430.

笹島隆彦・早川哲也・吉野真史・後藤智明（1996）：海水存在 時における風波の周波数スペクトル特性，海岸工学論文 集, 第 43 卷, pp.431-435.

合田良実 (2008)：耐波工学, 鹿島出版会, pp.327-379.

水田 亮・足立恭将・行本誠史, ·楠 昌司 (2008)：CMIP3 マルチモデルアンサンブル平均を利用した将来の海面水 温・海水分布の推定, 気像研究所技術報告, 第 56 号, pp.1-28.

水口陽介・林 誉命（2009）：網走港における設計沖波の検討 について, 北海道開発技術研究発表会論文集, 第 52 回

Janssen, P. A. E. M. (1991) : Quasi-linear theory of wind wave generation applied to wave forecasting, Journal of Physical Oceanography, No.21, pp.1631-1642.

Mizuta, R. et al. (2012) : Climate Simulations Using MRIAGCM3.2 with 20-km Grid, J. Meteor. Soc. Japan, Vol.90A, pp.233-258.

Wadhams, P (1975) : Airbone laser profiling of swell in an open ice field, J.G.R, Vol.80, No.33, pp.4520-4528. 